\title{
Modeling Public-Private Partnerships in Innovative Economy: A Regional Aspect
}

\author{
Tatiana Anopchenko, Olga Gorbaneva, Elena Lazareva, Anton Murzin * and \\ Gennady Ougolnitsky
}

Faculty of Management, Institute for Mathematics, Mechanics and Computer Science, Southern Federal University, Rostov-on-Don 344000, Russia; tuanopchenko@sfedu.ru (T.A.); oigorbaneva@sfedu.ru (O.G.); elazareva@sfedu.ru (E.L.); gaugolnickiy@sfedu.ru (G.O.)

* Correspondence: admurzin@sfedu.ru; Tel.: +7-863-218-4000

Received: 28 July 2019; Accepted: 8 October 2019; Published: 11 October 2019

\begin{abstract}
International experience demonstrates both the effectiveness and difficulties of using the mechanism of a public-private partnership (PPP) in solving socially significant problems of investment development of an innovative economy. The lack of tools to make an informed choice of the best PPP model in terms of the risks diversification is one of the significant problems of the predictive and analytical support of the relationship between business and government structures. The purpose of the study is to create and empirically test a multi-criteria modeling toolkit for the choice of the public-private partnership mechanism in relation to managing territorial sustainable development projects. Such problems as a structural representation of PPP risk factors and development of principles for their diversification, development of the algorithm and criteria for multi-criteria evaluation, testing of a multi-criteria model needed to be solved to achieve the research goal. The innovativeness of the author's approach consists in substantiating the algorithm of the multi-criteria modeling for the choice of the public-private partnership mechanism in relation to managing sustainable development projects of the territory. Criteria for alternative PPP models evaluating have been developed. Based on the results of testing, the advantages and disadvantages of applying the algorithm of the multi-criteria modeling in sustainable development management are identified, the directions for the model using in regional management are disclosed.
\end{abstract}

Keywords: multi-criteria modeling; hierarchy analysis method; public-private partnership; PPP projects risk factors; innovative economy' sustainable development management

\section{Introduction}

A public-private partnership is interpreted in Russian law as the cooperation of a public partner and a private partner concluded in order to attract private investment in the economy and based on pooling resources, sharing risks. The active process of introducing new approaches to project management of investment development of the economy using the mechanism of public-private partnership began in Russia about fifteen years ago with the adoption of the federal law "On concession agreements". The enactment of federal law 224-FZ "On public-private partnership (PPP), municipal private partnership in the Russian Federation and making changes in separate legislative acts of the Russian Federation" in 2015 accelerated this process in many sectors of public infrastructure, but did not create transparent rules for project management.

Three thousand four hundred and twenty-two contracted PPP projects with a total private investment of 2182 billion rubles are currently being implemented in Russia (minus completed projects). The biggest share in terms of both volume and number of projects are concessions. 2815 projects are 
implemented in the country under concession agreements ( $85 \%$ of the total number of projects), with a total volume of private investments of 1 trillion rubles ( $47 \%$ of the total) [1].

Federal projects, despite their scale, are still inferior in terms of total investment to regional ones. Twenty-four projects with private investments in the amount of 496 billion rubles are being implemented at the federal level. Here are projects such as the Central Ring Road, the «Platon» charging system, and others. There are twice as much private money-1.3 trillion rubles at the regional level. Although there are also more projects-356. The municipal level is a large number of small projects. There are 3042 of them, with a total volume of private investments of 368 billion rubles.

According to the estimates of the National PPP Center, 302 potential PPP projects are being prepared for launch in the country. Their potential volume is 1041.1 billion rubles. Of these, 283 projects with a private money volume of 166.3 billion rubles are already at the competition stage.

Such large federal projects as the HSR Yekaterinburg-Chelyabinsk with the volume of private investments of 180 billion rubles and the deep-water port in Arkhangelsk (123 billion rubles) are at the initiation stage.

There are no less large projects at the municipal level. For example, the modernization of centralized cold water supply and sanitation facilities in Samara. The total investment is 22 billion rubles (100\% private investment).

On the whole, in Russia, more than a thousand potential projects, where it is possible to use PPP mechanisms, are at the initiation stage. In monetary terms, this is more than 3 trillion rubles.

An analysis of the domestic practice of preparing and implementing PPP projects shows that the predictive and analytical support of the relationship between business and government structures requires toolkit to justify the best PPP model in terms of participants' risk diversification.

A conceptual platform for creating such a toolkit is the effective decision making as an important factor in ensuring competitiveness. There is a need to increase investments in public-private partnership projects (PPPs) as one of the most promising mechanisms for solving accumulated problems in various sectors of the regional economy. Public-private partnership is usually interpreted as an organizational and institutional alliance between business and the state, aimed at the implementation of socially significant projects in the fields of industry and research. Key criteria for classifying various types of partnerships as public-private categories are institutionalization, the presence of the government as one of the partners, the existence of joint goals and clearly identified state interest and joint investment of resources [2].

The need for public-private projects, as world practice shows, is especially connected with the innovative orientation of the modern economy. Public-private partnership for the purpose of mutually beneficial solution of important tasks for society in modern conditions is developing intensively both in the USA, Canada, many European countries, in which up to 20 percent of investment projects are implemented on these principles, and in Russia. However, unfortunately, Russia is still far behind in using this institution despite the historically established traditions of active state participation in the economy. In Russian conditions, public-private partnerships are most often implemented in the form of concessions and cover mainly infrastructure projects. Among the problems that slow the process of PPP development in the modern innovation ecosystem (business environment), it is necessary to highlight the high risks of this type of partnership as well as lack of a sufficient range of models for interests coordinating.

The main PPP models presented in Figure 1 can be used to coordinate the interests of state structures and businesses: DB (Design-Build) model, DBM (Design-Build-Maintain), DBO (Design-Build-Operate), and DBOM (Design-Build-Operate-Maintain) models. In addition, BOO (Build-Own-Operate), BOOT (Build, Own, Operate, Transfer), and DBFO, LCC concession (Design-Build-Finance-Operate), and several other models are used in practice [2,3]. The choice of one or another PPP model determines the degree of compliance with the interests of the parties in the implementation of projects of the sustainable development of an innovative economy. This choice is also important in terms of diverse project management tools. 


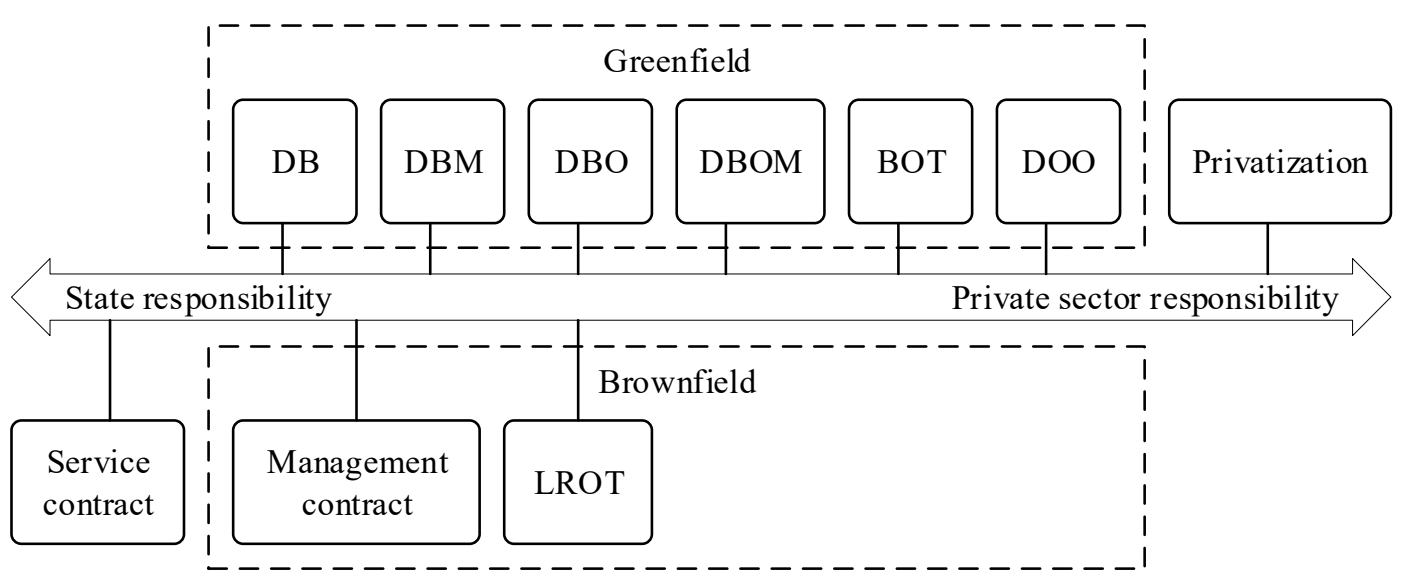

Figure 1. Models of interaction in the framework of public-private partnership (PPP).

Most models for reconciling of public and private interests are based on decision theory-the interdisciplinary theory aimed at developing methods and tools that help one or more individuals make an informed choice of the best available option [4-6]. Statistical and econometric methods (especially probit and logit models) are the commonly used tools of this theory. Parametric or nonparametric maximum likelihood methods are used to statistically evaluate such models [7-9].

It is difficult to use statistical (econometric) methods in the process of coordination of public and private interests because of the need to take into account how other decision makers in the situation will respond to the decision that is taken. The development and analysis of such PPP solutions is often carried out using mathematical tools of game theory, rather than decision theory [10-12].

The mathematical apparatus of game theory and modeling of hierarchical systems plays an important role in the formalization of the mechanism for coordinating the interests of public and private economic agents that is key to managing the regional sustainable development. The authors proposed an original integrated approach to modeling the coordination of private and public interests in the allocation of resources in hierarchical control systems in previous works [13,14]. The essence of the approach to modeling using the SOCHI (Social and Private Interests Coordination Engines) model is to find the so-called systemic consistency of interests of economic agents (public and private), which measures the set of optimally dominant (Nash equilibrium) strategies that maximize the social welfare function of the economic system.

The difficulties of adapting this approach to economic realities have initiated its development and addition with an expert-analytical multi-criteria decision making (MCDM) model for coordinating public-private interests in managing sustainable development projects based on the hierarchy analysis method of T. Saaty [15]. The central problem of MCDM modeling is how to evaluate a set of alternatives in terms of a number of criteria [16]. Solution to this problem required a structural analysis of risks and models of public-private partnerships. Based on the results of the analysis, evaluating criteria and alternatives are proposed, an algorithm for modeling a multi-criteria assessment and selection of the best PPP model from the point of view of minimizing risks is developed.

Our goal is to develop a decision support toolkit in the management of PPP projects by developing a new modeling concept and a multi-criteria assessment algorithm and choosing the best PPP model in terms of risk diversification. This new approach will allow public and private partners to assess the degree of compliance with their interests when choosing a PPP model and to formulate strategies for participation in the implementation of PPP projects.

The results of the research are presented below as follows. Section 2 details the features of analysis hierarchy method - the main research instrument in the paper. Section 3 is devoted to the development of a multi-criteria model of matching interests in relation to the public-private partnership in managing projects for sustainable development of the territory. Section 4 discloses and empirically substantiates 
the directions for using the multi-criteria model for coordinating interests in regional management. Section 5 provides final considerations and conclusions.

\section{Materials and Methods}

For a multifaceted assessment and selection of the best PPP mechanism from the point of view of risk diversification, the authors developed a software product that allows public and private partners to use the proposed MCDM model to monitor the degree of compliance with their interests and make managerial decisions.

This article develops the research [14], which describes the methodology and the model toolkit for managing the sustainable development of the region. The proposed methodology was based on the idea of combining econometric, simulation, and expert modeling methods into an integrated system for managing the sustainable development of a territory. Regional information-analytical support system is creating to implement the sustainable management methodology. This system has a hierarchical structure, and the subsystems at the lower levels of management can be used independently.

The simulation subsystem of the analytical block implements the modified well-known Solow growth model [4] using data from the regional data warehouse. This model sets important constraints in solving optimization management problems [13]. The optimization and expert subsystems of the analytical unit provide a solution to the problem of harmonizing public and private interests in the sustainable economic management.

The processes of coordination of public and private interests are based on a fairly wide range of mathematical tools, mainly optimization. At the same time, the practice of making management decisions by economic entities allowed to outline the main features of such tasks: Multidimensionality, the need to simultaneously take into account when choosing alternatives of several targets, the need to evaluate alternatives from the perspective of a fairly wide range of criteria, difficulties (sometimes impossible in principle) to form conditions for implementing alternatives, factors criteria, and goals in quantitative form. Among the circumstances that complicate decision-making is the presence of a sufficiently large number of decision makers. These circumstances make it difficult to use the already traditional mathematical methods $[17,18]$.

Due to this, the traditionally used mathematical methods for matching interests have been supplemented by authoring tools developed on the methodological foundation of the hierarchy analysis method by T. Saaty as a recognized method of supporting management decision-making through the hierarchical composition of the problem and multi-criteria rating of alternatives [15].

The advantages of the toolkit in terms of supporting the process of harmonizing public and private interests are as follows:

- The hierarchical structure of the method reflects the interrelationship of alternative solutions with the factors on which they depend, as well as with the criteria for rating them, which visualizes the participants' views on the situation of decision making;

- The use of tools requires a focused collection and grouping of information that provides a decision-making process, and also allows you to assess the quality (accuracy and consistency) of data;

- As a result of modeling the decision-making situation, it is possible to more adequately assess the influence of one or another factor on the priorities of decisions by identifying the most significant factors;

- The use of the method makes it possible to identify the "boundaries" of the stability of the ratings and to determine the likely situations of change in the decision.

The hierarchy analysis method (HAM) is a systematic procedure for the hierarchical representation of the essential elements of a problem situation, the resolution of which is aimed at making the management decision by the subjects-public-private partnership participants. This procedure consists in the decomposition of a specific problem into more and more simple components (from 
the goal to the comparable solutions to the problem-alternatives) and further processing of the sequence of decision judgments by pairwise comparisons. As a result, the relative degree (intensity) of interaction of elements in the hierarchy can be expressed. These judgments are then expressed numerically. The hierarchy analysis method includes procedures for synthesizing multiple judgments, obtaining priority criteria, and finding alternative solutions.

The hierarchy analysis method is based on the principles of: Identity and decomposition, discrimination and comparative judgments, and the principle of synthesis.

The principle of identity and decomposition involves structuring problems in the form of a hierarchy or a network, which is the first step in the application of the method. The hierarchy is built from the top (goals), through intermediate levels (primary factors, subjects, and criteria on which subsequent levels depend) to the lowest level (which is a list of alternatives).

The decomposition of the problem consists in dividing it into hierarchy levels so that the elements of the lower level of the hierarchy are comparable in pairs to the elements of the next level up to the top of the hierarchy (the law of hierarchical continuity). Thus, subject to the law of hierarchical continuity, all elements of one level are identical to each of the elements of the next level.

The principle of discrimination and comparative judgments comes into effect after the hierarchical/network reproduction of the problem and provides for a pairwise comparison of the elements of the hierarchy. During the survey, the elements of the task are compared in pairs to their effect ("weight", or "intensity") on their common characteristic.

The principle of synthesis is used to combine the results of hierarchical decomposition and comparative judgments to form a multi-criteria assessment of the public-private partnership models. For this, a set of local priorities of the assessment procedure is sequentially formed from groups of matrices of pairwise comparisons; the relative value (probability) of each individual element is calculated through the "solution" of matrices having inversely symmetric properties, synthesized by multiplying local priorities and priorities of the evaluation criteria, as well as summing up the element in accordance with the criteria that this element affects the global (composite) priorities of the elements of the PPP model assessment. The global priority of a particular element is then used to weigh the local priorities of the elements that are compared to it as a criterion and located lower level. The procedure continues to the lowest level.

The so-called consistency index is a very useful tool. It provides information on the degree of violation of expert assessments consistency. When the degree of deviation from the level of consistency exceeds the established limits, the one who makes the judgments should double-check them in the matrix of paired comparisons.

An important advantage of the hierarchy analysis method is its ability to measure the quality characteristics of the system. This is achieved with the help of more precise formulations of goals and research objectives than in standard assessment methods, which simplifies the procedure for checking and controlling the subsequent application of the analysis results. Moreover, the hierarchy analysis method can be used as a tool for measuring quality, including in the hierarchy assessment criteria, by means of which the actual quality of the system is compared with the desired one.

Justification of the criteria and multi-criteria assessment of PPP models would allow potential project participants to predict risks and evaluate strategies (tools) for their minimization (diversification). The proposed three-stage algorithm will evaluate alternative PPP models from the point of view of observing the interests of various interested parties (participants): Government and public structures, business. This unique toolkit allows you to integrate four aggregated factors when evaluating PPP models—criteria that are important for choosing a PPP model: Economic, social, managerial (institutional), and environmental.

Multi-criteria model of the coordination of state and business interests in the management system is a step-by-step process of setting priorities. At the first stage, the most important elements of the problem are identified; at the second - the best way to verify the observations, test, and evaluate the elements; the next step may be to develop a method of applying solutions and assessing its quality. 
The whole process is subject to verification and rethinking until there is confidence that the process has covered all the important characteristics necessary to present and solve the problem.

When applying the three-stage evaluation algorithm, the evaluation criteria and indicators were determined sequentially, a group of experts was formed; expert assessment and analysis of private and general indicators of PPP models assessment, calculation of the integral assessing indicators, and the decision (to choose/not to choose a PPP model) making were made.

Following stages of PPP models assessing process were required in order to realize the three principles of the hierarchy analysis method (Figure 2):

- The preparatory stage at which the objectives of the evaluation were formulated, the selection of criteria and indicators for evaluation, as well as of techniques for its implementation were carried out. At the same stage, the collection and preliminary processing of analytical information was carried out;

- The main stage, which included the analysis of risk factors and conditions of the alternative PPP models implementation; calculation and analysis of private and general indicators of PPP models estimation; and calculation of the integral indicator of PPP models assessing;

- The final stage- the stage of generalization of the results of the PPP models assessment and the decision to choose/not to choose a PPP model making.

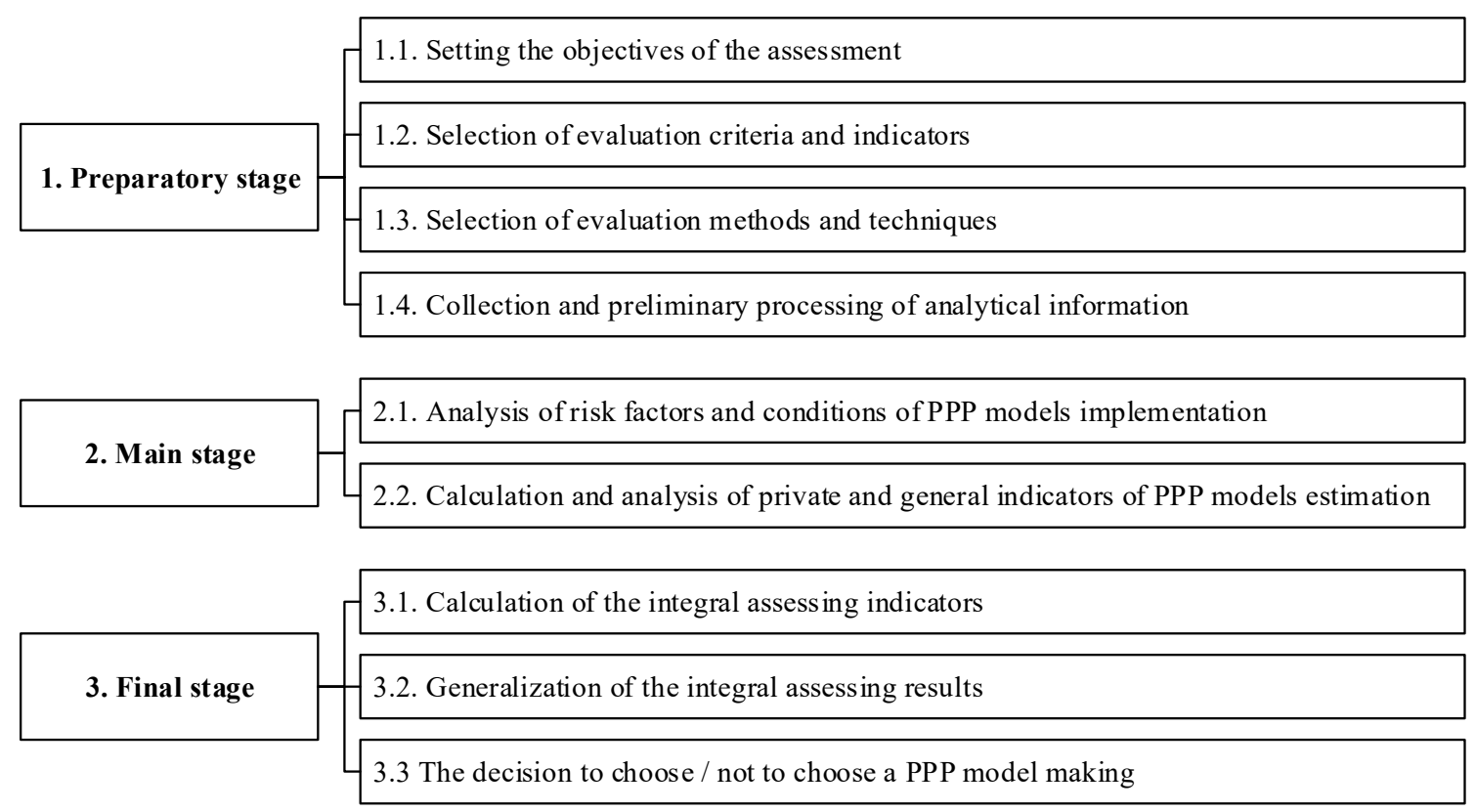

Figure 2. Algorithm for multi-criteria evaluation of public-private partnership models.

A group of experts was formed to implement the evaluation procedure for PPP projects. This group consisted of five experts-representatives of interested parties in the region of the Russian Federation (Rostov Region)—the Investment Development Department of the Ministry of Economic Development of the Rostov Region, the autonomous non-profit organization National Center for PPP (a key institution for the development of PPP in Russia), business structures actively involved in the implementation of PPP projects, as well as social and environmental organizations.

We used official data from Rosstat and its regional branches, the Ministry of Economic Development of the Russian Federation, data from the ROSINFRA PPP project information support platform (pppi.ru), as well as information and analytical materials contained in the works of Russian and foreign researchers on the problems of developing mechanisms to increase the effectiveness of partnership between the state and business [1-3,19-22] as the information and empirical base for the expert analysis of risk factors and conditions of PPP models implementation. 
The legal framework of the study was the Civil Code of the Russian Federation and the Federal Laws of the Russian Federation, which regulated the interaction of the state and business in the development and implementation of projects.

\section{Results}

The main strategic documents on the basis of which Russian PPP projects will be developed in the coming years are national projects. There are 13 of them, with a total value of 25.7 trillion rubles. 7.7 trillion rubles among them are extra budgetary funds. The national project is a comprehensive program for the main areas of activity: Transport, education, ecology, demography, housing, etc. According to these documents, investments in water supply and sanitation projects occupy a relatively small share in the volume of investments in the main infrastructure sectors. This reflects the global situation ( $\$ 188.8$ billion of global investments in water supply and sanitation projects in 2018 with world transport costs of $\$ 1292.8$ billion, and energy and communications costs of $\$ 850.3$ and 273.6 billion respectively) [1].

Nevertheless, in many regions of the Russian Federation, the reconstruction of water supply and sanitation systems is included in the list of priority infrastructure projects. Rostov region is one of such regions.

The effectiveness of the MCDM modeling of the coordination of interests in the management of eco-development projects of the territory could be demonstrated by the example of the project "Pure water of Rostov-on-Don" ("A comprehensive program for the construction and reconstruction of water supply and sanitation facilities in the city of Rostov-on-Don"). This project was aimed at the development of water supply and sanitation systems of the Rostov agglomeration.

The project was financed from the budgets of the Investment Fund of the Russian Federation, Rostov Region, Rostov-on-Don, and the funds of a private investor-Rostovvodokanal JSC, which is part of the Eurasian JSC group of companies. The main economic goals of its implementation were improving the quality of services and developing the infrastructure of water supply and sanitation in Rostov-on-Don; reducing the negative impact of economic activity on the state of the Don River.

The project was implemented using the mechanisms of the Investment Fund of the Russian Federation in the form of grants from the budget of the Russian Federation to the budget of the Rostov region for the provision of a corresponding subsidy to the budget of the city district of Rostov-on-Don.

The project was also aimed at obtaining social and environmental effects (providing 6 million square meters of housing construction (330 thousand inhabitants) and 2 million square meters of commercial real estate; improving living conditions-connecting to centralized water services of up to $98 \%$ of the city's population (an increase of 22 thousand inhabitants); compliance with the requirements of the current legislation on environmental protection-excluding discharge of untreated industrial effluents (about 40 thousand cubic meters per day) into the Don River.

The national coordinator of the project was the Government of the Rostov Region, and the state customer and the responsible executor was the Administration of Rostov-on-Don. The Vodokanal Production Association of Rostov-on-Don (the main investor and executor of the project) was participating in the project as the main business structure.

The need to manage this eco-project was caused, on the one hand, by the considerable deterioration of the existing of water supply and sanitation system, and on the other hand by the lack of interest of the business in such projects implementing.

The problem was complex and required a multi-criteria approach. For a balanced and sustainable solution of the problem, according to the authors, a model of public-private partnership was needed, which would allow it to relate, on the one hand, interests and benefits, and, on the other hand, the means and efforts to create water supply and sanitation systems.

Figure 3 shows the hierarchical structure of factors, subjects, criteria, and alternatives, which were presented to a group of experts as a chain of possible influences on a multi-criteria assessment and choice of a PPP model (Figure 3). 


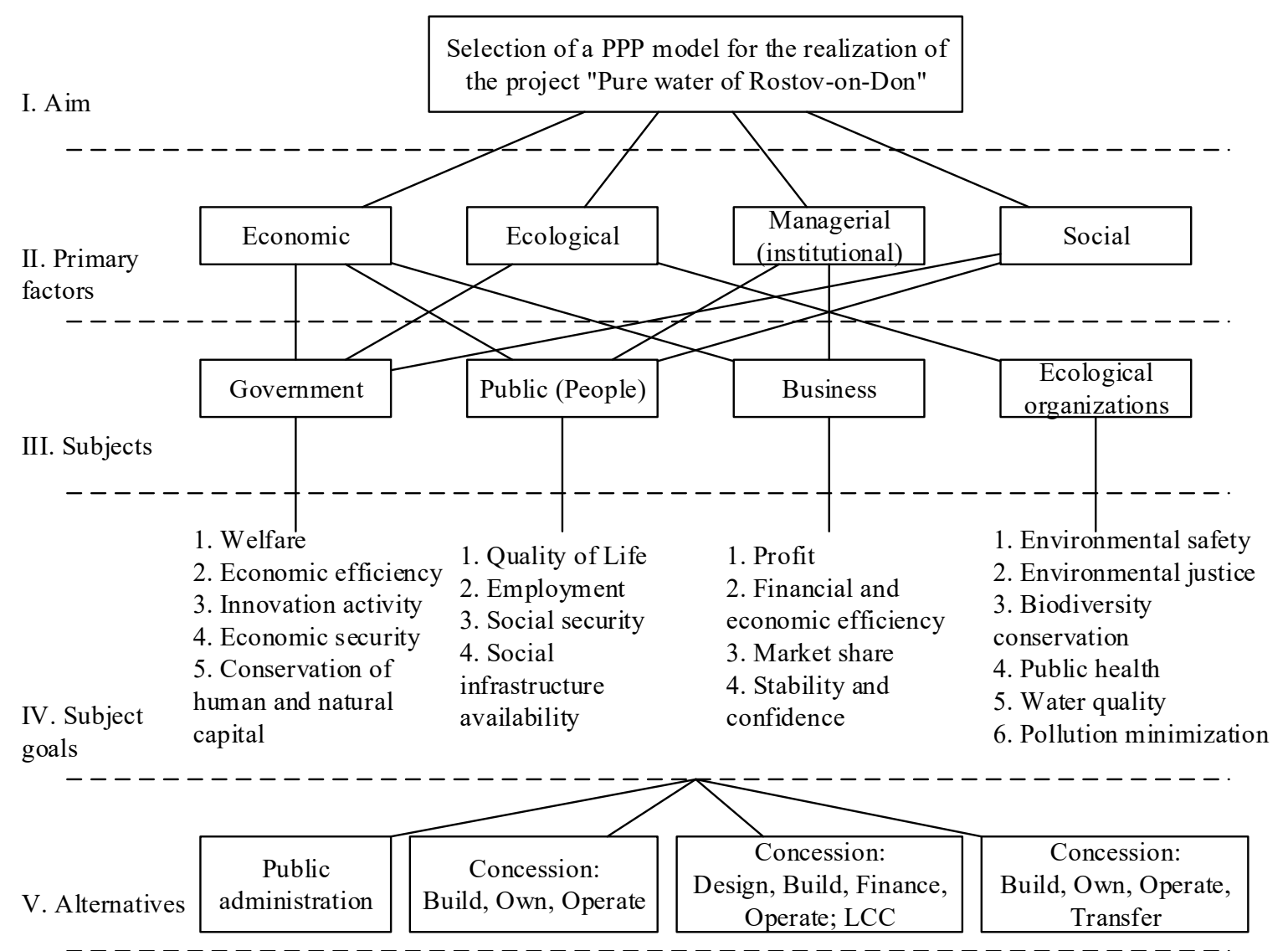

Figure 3. Hierarchy for choosing a public-private partnership model in eco-project managing.

One of the main tasks of the preparatory stage was the selection of criteria, which was that it was necessary to decide on the basis of which characteristics would be evaluated. Criteria for evaluating models of public-private partnerships must meet the requirements of realism (attainability and consistency during the analyzed period), specificity (compliance with the content of the project participants' activities), efficiency (determined by linking the assessment results with actual performance indicators of the subject), dynamism (evaluation criteria should evolve), and reliability (ensuring consistency and consistency (consistency) of measurement results) [23]. When choosing indicators that allow assessing the conformity of an assessment of a public-private partnership model with the selected criteria, one should also rely on the principles of controllability (ability to influence the value of estimated indicators through control actions), elasticity (sensitivity to changes in factors), uniqueness (measurement of a single qualitative characteristic), and also profitability (the data necessary for calculating the indicator should be searched and processed with minimal cost of resources).

The selection of criteria for evaluation needs various PPP risks analyzing. Significant PPP risks are mainly determined by the fact that partnership between the state and business should be viewed as a complex structured and constantly evolving adaptive system built into the world innovation ecosystem. Difficultly predictable characteristics of variability in such systems inevitably affect its agents, their relationships, which, as a rule, initiate the appearance of new emergent properties and the system as a whole. The consequence of the described chain of influences is the emergence of ever new risks of interaction between partners (political, operational and commercial, and construction and financial risks).

In addition, we could distinguish some risks of the state and business interaction, which negatively affected the processes of project management investment attractiveness formation. Among them: 
- Refusal of private business to participate in tenders due to an inability to create an adequate business plan, taking into account state restrictions and fears of transferring all risks to the private sector;

- Discrepancy in the implementation of financial interests of public and private partners due to the asymmetry of the information available to them;

- The opportunistic behavior of both partners in one way or another;

- The extreme complexity and "entanglement" of many PPP models;

- The fear of a state partner, associated with the risk of possible bankruptcy of a private partner and full responsibility for the project, which hinders the conclusion of a partnership agreement at the initial stage.

Risk minimizing is inextricably linked with their diversification and requires the use of a spectrum of various adaptive management tools that adapt to variations in the endogenous and exogenous parameters of the system. Managerial responses to external influences formed by the world innovative business environment-risk factors are very diverse and differentiated depending on the nature of these «tremors» [24].

Thus, in response to the so-called «collapse risk» (the risk of aging of the PPP model due to the above-mentioned fluctuations), it is necessary to increase/provide heterogeneity (diversity) of the ideas and innovations used, as well as personnel and spheres of activity in general. To mitigate the «risk of infection", the risk of rapid diffusion of disturbances arising at a single «point» of the global innovation ecosystem of shocks can be achieved by ensuring the modularity of the PPP system, and the risk of «thick tails» (large/strong shocks, for example, natural disasters) by duplication and redundancy, due to which, as a rule, the elements of the system manage to minimize/repay negative impacts. With regard to mitigating the risks of violation of the integrity of the PPP project due to sudden changes in the world innovation ecosystem, the main tool for adaptive management is evidently the identification of patterns of such variations, a detailed analysis of the incoming «signals» and taking measures to prevent a negative outcome. The key point is the analysis of possible effects of the introduction of new technologies and the adoption of preventive measures to diversify the emerging risks of unfavorable development. An example of a successful application of this tool can be the actions of the company-the manufacturer of household optics «Essilor». The company, responding to the «signal» of the ecosystem, quickly introduced the technology of digital lens processing, absorbed the competitor-the company «Gentex» and entered the world leaders in the production of polycarbonate lenses.

Due to the inconsistency in the separation of different types of PPP risks between participants/ partners, many projects do not reach the implementation stage. The mutual coordination of the mechanism for the separation of risks becomes possible only with their systematization and the development of principles for the diversification of various types of risks. Thus, the systematization of risks of various types of concession projects-from BOT (Build-Operate-Transfer), BTO (Build-Transfer-Operate), to Build-Own-Operate, Build-Own-Operate-Transfer, and BBO (Buy-Build-Operate)-allowed it to offer a justified in practice mechanism for their distribution between the concessor and the concessionaire [21].

The main political risks of the PPP project (expropriation, dissolution of the concession by the state, political events, limitation of currency convertibility, etc.) are assumed by the concessor-the state that granted the concession. The main operational risks (the risks of negative impact on the environment and occurrence of force majeure events, as well as technological risk and the risk of exceeding the planned costs) fall on the side of the concessionaire. The state is only responsible for some operational risks (such as risks of force majeure events and/or changes in the specification).

As for the risks of not completing the construction on time, their distribution between the parties is equally divided: Responsibility for the risks of acquiring land, exceeding costs due to changes in the project, in the specification and quality of work, as well as for the risks of delays in time due to administrative procedures and bankruptcy of the concessionaire's company bears a concessor; approximately the same number of risks includes the zone of responsibility of the concessionaire-these 
are risks of exceeding costs, excluding changes in the project, and increasing financial costs, risks in the specification, and quality of work, delays in time due to administrative procedures, and losses incurred in the performance of work. Commercial risks (falling in traffic, price management policies, and construction of competing facilities), legal risks (permits and licenses, and litigations), as well as financial PPP risks (inflation, interest rates, and exchange rates) are generally not subject to diversification, responsibility for them are borne by both partners of the project.

Mitigation of PPP risks is impossible without a well-grounded investment policy, the purpose of which is multi-channel attraction of investments, not only in the form of direct financing of priority projects, but also by creating a favorable investment climate. From the point of view on the selection procedure, investment decisions based on multi-criteria evaluation of a number of, as a rule, multidirectional economic, social, and environmental risks and trends, are among the most difficult.

Indicators of social, ecological, and economic efficiency serve as criteria for state support of such project decisions (Table 1). In evaluating the project, in many cases, not only financial, but also economic analysis must be carried out. Unlike financial analysis, which its task is to study the flow of money, market prices, and economic analysis should clearly monitor the overall economic value, taking into account the social and environmental consequences of development projects, regardless of whether they are reflected in the market or not.

Table 1. Criteria for competitive selection of PPP projects.

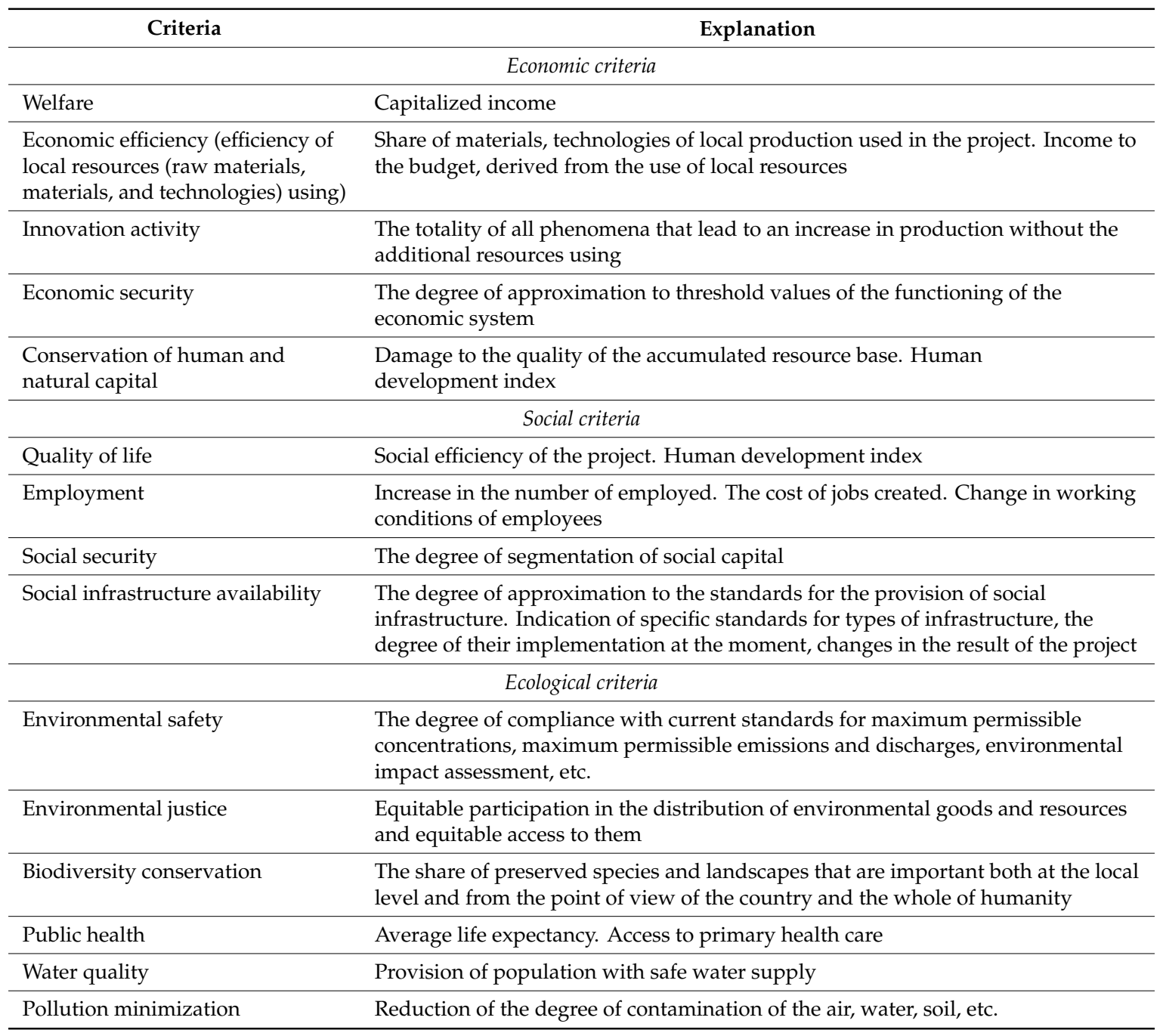


The foundation for the selection of criteria for the four aspects evaluation of projects is the model of sustainable development created by the world community. Within the framework of such a model, economic efficiency and economic security, social justice and social security, and environmental development security must be simultaneously ensured.

In the economic evaluation of PPP projects, one should rely on an economic interpretation of sustainability as a volume (quantity) of consumption, which can be continued indefinitely without destroying capital reserves, including reserves of "natural capital". The emphasis is on scientific and technological progress as a key area for increasing development efficiency.

Economic criteria are largely developed in order to find the space of economic interaction between the state and business.

Economic efficiency and economic security as well as the level of well-being and preservation of the human and natural capital, the innovative activity of economic entities are the most important goals of the state.

The achieved level of well-being is both the result and the basis of economic development. The measurement of this level in modern conditions involves taking into account not only material elements, but also significant in the conditions of innovative transformations of intangible components [25]. Economic efficiency can be defined as the ratio of the results obtained to the costs or resources consumed.

The importance of such criterion as innovation activity is determined by the innovative nature of modern economic growth $[25,26]$. The innovation activity of economic agents may be defined as the totality of all phenomena that lead to an increase in production without the additional resources using. Innovations affect the results of economic development through the introduction of more advanced equipment and technologies into production process, or through special measures to improve the skills of the workforce. These improvements can take the form of a time-dependent econometric (correlation-regression) function. The example of construction of such function for the analysis of innovative activity of economic agents of the Southern Federal District is described in detail in [27].

An important economic criterion is economic security. That is, how the national economy is protected from those internal and external negative factors that disrupt the normal functioning of reproduction. This criterion is closely related to the criterion of conservation of human and natural capital. Since economic security is ensured through the efficient use of all types of accumulated capital.

Social criteria are focused on people and maintaining the stability of the social and cultural system. Important aspects of this approach are equality and justice in the distribution of income, as well as the participation of the population in the decision-making process.

From an environmental point of view, sustainable development should ensure the stability and viability of "natural" systems. The main attention is paid to the preservation of self-healing abilities and the dynamic adaptation of such systems to changes. Degradation of natural resources, environmental pollution and loss of biological diversity reduce the ability of ecological systems to self-repair.

The foundation of accounting when assessing the characteristics of the ecological environment is the work of two authors, namely, R. Solow and J. Hartwick, who introduced the rule of sustainable management (the rule of maintaining a constant level of consumption of non-renewable resources based on rent reinvestment from its use in the man-made capital), usually known as Solow-Hartwick [28,29].

As for the alternatives to achieve the goal, among them were considered variants of public administration and three typical models of public-private partnership, fundamentally differing from each other in how, to which side, and at which point in time the property rights are transferred to the object, as well as the degree of responsibility and shares its distribution among partners.

In this particular case, three concession models were chosen as alternative PPP models-BOO (Build-Own-Operate), BOOT (Build, Own, Operate, Transfer), and DBFO, LCC concession (DesignBuild-Finance-Operate). This choice is explained by the fact that these types of PPP models, along with administrative methods of state regulation, are most applicable in the field of managing eco-projects for sustainable development of Russian regions [19]. 
DBFO, LCC concession (Design-Build-Finance-Operate)—a private partner carries out the design, financing, construction, and operation of a new infrastructure facility that can be owned by both a private and a public partner. The private partner transfers the specified object to the public partner upon the expiry of the term indicated in the project agreement. LCC is a type of DBFO concession. This model is a special form of the DBFO model, in which the design and construction of the facility is carried out entirely by the contractor, but at the same time, all financial risks are taken by the state, and the return of funds to the contractor is presented in the form of deferred payments.

The BOOT (design) - Build-Own-Operate-Transfer concession provides for a private partner to receive financing, design, construction, and operation of the facility, including charging for use, for a certain period after which the right of ownership is returned to the state; in this case, the private partner receives not only the authority to use, but also ownership of the infrastructure facility during the specified period.

A modification of the BOOT model is also (D) BOO (design)-Build-Own-Operate-in which the concessionaire retains ownership of the object on an ongoing basis, the period is not limited. This model implies the greatest freedom for a private partner in making decisions, which creates opportunities for obtaining short-term personal gain to the detriment of the goals that are set for the project. Moreover, it becomes dangerous, the smaller the project is of commercial interest.

The alternative «Public administration» implies the direct or indirect impact of state legislative bodies. It may be, for example, an increase in fines for exceeding the permissible norms of environmental pollution or toughening the norms of maximum permissible discharges, which will make the work of enterprises according to the current model (dumping waste in the river) economically inexpedient and will force them to independently introduce resource-saving technologies. An example of a direct impact could be a ban on conducting production activities of certain areas without establishing an appropriate system for the treatment of industrial wastewater.

Traditionally the hierarchy analysis method is an expert method, i.e., the assessment of the selected criteria of the system is carried out by experts in a certain field. We have transformed this method taking into account the objectives of the study and the evaluating "expert" in our case is each of the participants of public-private relations in the implementation of certain territory sustainable development projects. The implementation of the procedure of pairwise comparisons is based on a measuring scale of relative importance, the two key requirements for which are the limb and the coverage of as many gradations as possible. The scale that meets these requirements is given in Table 2 [15].

Table 2. Relative importance scale for comparing hierarchy elements.

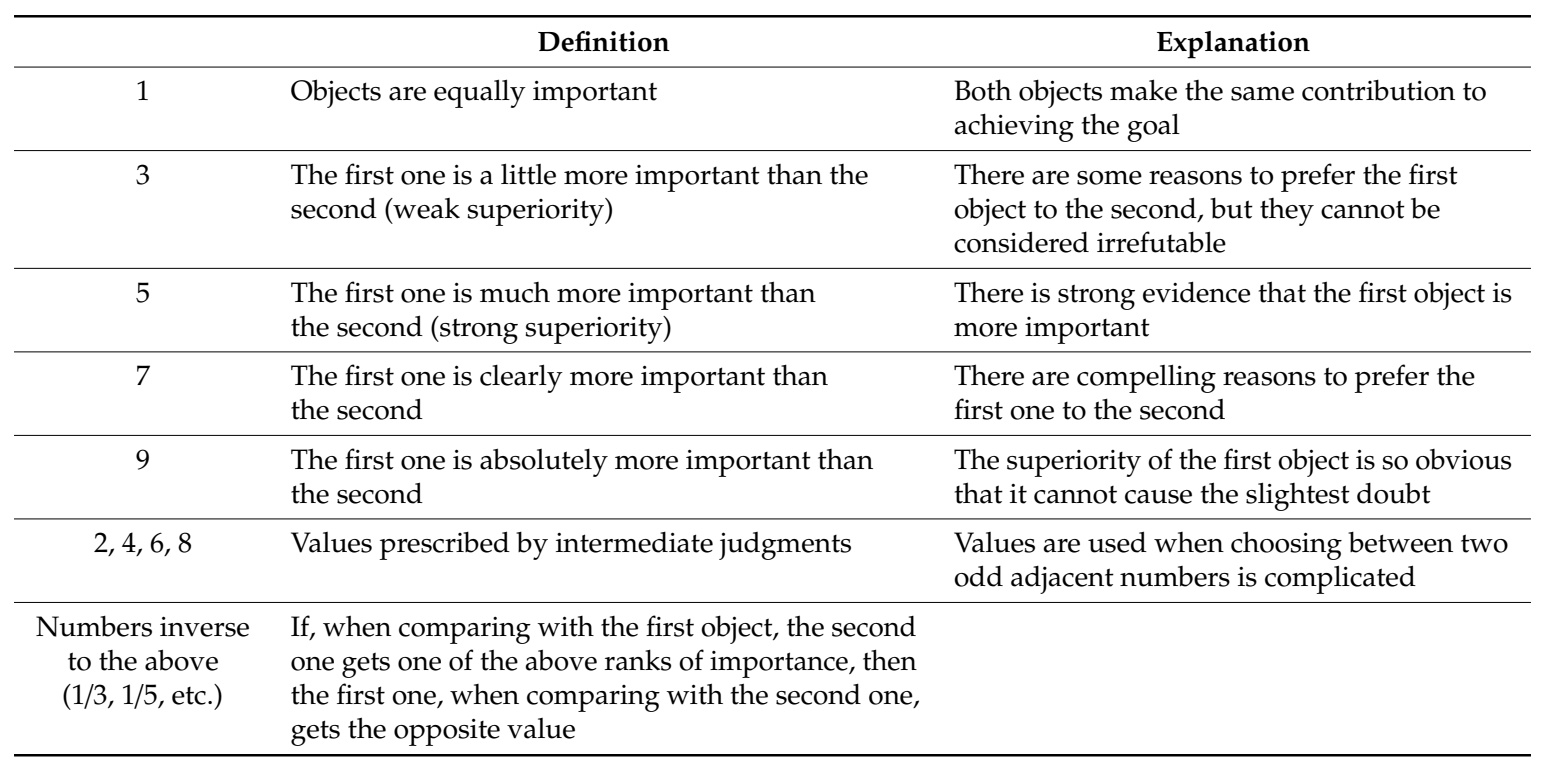


The procedure for applying the hierarchy analysis method to determine the best PPP model (in accordance with the chosen alternatives) is based on the implementation of the following steps at the main stage of the assessment:

(1) Building a hierarchy, starting from its top (goal—the PPP models evaluation), through intermediate levels (criteria) to the lower level, which is a list of alternatives;

(2) Building a set of matrices of pairwise comparisons for each of the lower levels. Each matrix of the level $i$, consisting of $\mathrm{n}$ elements, is an inverse-symmetric matrix of $\mathrm{n} * \mathrm{n}$ size, which is oriented to one of the criteria of a higher level. Such a criterion is called a guided element with respect to a lower level element. Elements of any level are compared with each other regarding their impact on the guided element;

(3) Judgments are required to obtain each matrix of $n * n$ size. This requirement is fulfilled either when it is possible to quantitatively measure the weight of each element, or in the expert scores on a predetermined scale of relative importance. If element A dominates over element $B$ by some criterion, then the cell at the suppression of row A with column B is filled with a positive integer, and the cell corresponding to row B and column A is inverse (fractional) to it. With the same values of the weights of elements A and B, units (1) are put in both cells;

(4) Determination of eigenvectors of pairwise comparisons matrices, which is used to calculate the consistency index of each matrix;

(5) Carrying out stages 2, 3, and 4 for all levels of the hierarchy;

(6) Weighting the priority vectors of alternatives with criteria weights and calculating the sum over all the corresponding weighted components of the priority vectors of the hierarchy level below;

(7) Finding the consistency of the entire hierarchy by multiplying each consistency index by the priority of the corresponding criterion and then summing up the received works.

Consider the results of the multi-criteria assessment of the relative importance of the criteria for the implementation of this project in particular, as well as eco-projects for the development of the territory as a whole.

The project is based on ideas of primarily ecological nature-the mission is a sustainable solution to the problem that has arisen in the environmental dimension of the situation. A number of subcriteria from neighboring groups are in some way connected with the subcriteria of the environmental group. The project under consideration is aimed at solving environmental problems as the most significant. In the most eco-development projects of the territory, the ecological group of criteria will receive the greatest weight. This is the main focus of the eco-project. Thus, environmental criteria took almost half the weight of the criterion of «importance» (0.41; Table 3).

Table 3. Importance of interest groups estimation in the eco-projects management.

\begin{tabular}{lcccccc}
\hline & Expert 1 & Expert 2 & Expert 3 & Expert 4 & Expert 5 & Own Group Vector \\
\hline Economic criteria & 0.1051 & 0.1031 & 0.0862 & 0.1036 & 0.0942 & 0.0984 \\
\hline Ecological criteria & 0.4457 & 0.4841 & 0.4348 & 0.3109 & 0.3718 & 0.4095 \\
\hline Administrative criteria & 0.2848 & 0.2519 & 0.3075 & 0.4397 & 0.3718 & 0.3311 \\
\hline Social criteria & 0.1644 & 0.1609 & 0.1715 & 0.1458 & 0.1623 & 0.1610 \\
\hline Consistency Index & 0.0214 & 0.0521 & 0.0862 & 0.0388 & 0.0373 & 0.0472 \\
\hline Consistency Assessment & 0.0238 & 0.0579 & 0.0957 & 0.0431 & 0.0415 & 0.0524 \\
\hline
\end{tabular}

The second place in terms of «importance» was taken by managerial criteria (0.28). In the city of Rostov-on-Don, it is critical in the near future to solve the problems associated with the deterioration of the water supply and sanitation system. The solution of managerial problems that require a quick response makes it possible to normalize the work of the administration with problems of a larger scale 
in time and, as a result, to ensure the achievement of strategic goals in the development of the city. Thus, the project contributes to solving more global problems, and in the long term the sustainable development of the region as a whole.

The third place was taken by social criteria (0.16). Social problems are largely due to environmental and citywide problems. Solving social problems themselves, if it requires separate efforts, is impossible without achieving environmental security for the health of citizens, as well as city-wide conditions for meeting the needs of the population that meet a certain quality of life.

Economic criteria ranked last, fourth in importance of implementation in an eco-project. The reason for this assessment is that many environmental goals do not imply tangible returns in a time perspective that is attractive to private business. The consequence of this assessment is the need for the presence of the state as a partner, compensating for their participation in one or another degree of "unprofitability" of a certain eco-project.

In the identified "coordinates» of interests, it is necessary to further study which model of a public-private partnership will be the most balanced in meeting the criteria presented considering their "weights" (Table 4).

Table 4. The final values of the priorities of the alternatives.

\begin{tabular}{|c|c|c|c|c|c|}
\hline & Economic & Ecological & Administrative & Social & Priority \\
\hline & 0.0984 & 0.4095 & 0.3311 & 0.1610 & Summary \\
\hline Public administration & 0.0688 & 0.1037 & 0.2645 & 0.1444 & 0.1601 \\
\hline $\begin{array}{l}\text { Concession: Design, Build, } \\
\text { Finance, Operate; LCC }\end{array}$ & 0.4575 & 0.2111 & 0.1491 & 0.3330 & 0.2344 \\
\hline $\begin{array}{l}\text { Concession: Build, Own, Operate, } \\
\text { Transfer }\end{array}$ & 0.3882 & 0.5906 & 0.5493 & 0.4820 & 0.5395 \\
\hline Concession: Build, Own, Operate & 0.1769 & 0.0946 & 0.0371 & 0.0406 & 0.0750 \\
\hline
\end{tabular}

The BOO (0.07) concession had failures in almost every relative assessment of compliance with the criteria, except for economic ones. This was explained by the fact that the greatest freedom in making decisions with a private partner would lead to the search for short-term gains with the possibility of neglecting the interests of other parties.

The DBFO, LCC (0.23) concession had failures in respecting managerial interests, as the private partner could use the opportunity to compensate costs, artificially overestimating the cost of the project and postponing its implementation, which would also reduce the useful environmental effect of the project.

Public administration (0.16) had a strong failure to comply with economic interests. Such effect might adversely impact on the economy of the region as a result of, for example, a reduction in production lines due to their unprofitability caused by increased fines or stricter waste control. In addition, this method would provoke corruption or the departure of enterprises in the shadow sector of the economy.

The most sustainable alternative was the BOOT (0.53) concession model. In the case of its implementation, it is necessary that the state controls and finances the activities of the private partner at the design and construction stages. The private partner, choosing technologies, interacting with future partners, the supplier of works, and equipment realizes its advantages in its flexibility and ability to adapt. As a result, a locally optimal water supply and sanitation system was built, taking into account the specifics of specific enterprises, territory, city district, etc. After that, during the tenure of the property and management, the private partner carried out improvements, system refinement, and its optimization from a business point of view, while not losing state support, which also needs to be described. Upon the expiration of the service life, the object was transferred to the state, which in the future was recruiting staff that would continue to control a full-fledged system. A private partner 
gained valuable experience, built a business model that could then be copied and scaled, and also made promising connections, which expanded its possibilities for future capital investment.

The advantage of the presented assessment procedure was that obtaining private and generalized assessment indicators for each block made it possible to identify reserves for enhancing the interaction between the state and business, making adjustments if necessary through control actions.

\section{Discussion}

The algorithm of the public-private partnership modeling in regional sustainable management provided a solution of the multi-criteria problems with a simple and reasonable toolkit. It included tools for the measurement of quantitative and qualitative factors of different dimensions. The proposed algorithm revealed the possibilities of the hierarchy analysis method. However, the problem of evaluating criteria and alternatives justification was urgent and required a wide range of research activities.

PPP risks were often not controlled by a private investor. Their control was a priority function of the state (for example, risks of introducing technological standards, and commissioning of a sewage treatment plant); a significant portion of the investment was usually spent at the initial stage of project implementation, where the benefits were slow and incomes could be problematic. The main tasks to be solved by the state on the path of activating socially significant investments and overcoming the shortcomings of modern research of the investment attractiveness of Russian regions through strategic development of the risk management system for public-private partnership projects are:

- Intensification of state measures to create a favorable investment climate in accordance with the balance of interests of investors and recipients of investment on the basis of integrated investment assessments;

- Legislative enactment of investment conditions that meet this principle.

As mechanisms for reducing risks for creating favorable conditions for foreign investors in the regions of Russia, it is necessary to consider:

- Project risks distribution among a wide range of participants;

- Credit syndicate with the participation of a "chain" of banks and financial companies: local level, regional level, federal level, and international level, which is a "financial conveyor" as a whole organization;

- Use of mechanisms of deep preliminary expert preparation of projects for financing, and also the use of mechanisms of preliminary coordination of all "project chain";

- PPP project multifactorial monitoring channel (independent from the project management) availability.

The models for coordinating public and private interests can undoubtedly find their application in the regional management system both in coordinating the interests of participants in PPP projects and in developing a cooperation mechanism in cross-border areas (local production and trade contacts in border areas; long-term interactions based on agreements on cooperation of individual organizations/territorial units; temporary network cooperation agreements implementation of certain cross-border projects in individual areas, forms of spatial (inter-regional) integration of a new type-cross-border clusters, development corridors, etc.).

Examples of successful PPP projects are infrastructure projects implemented with the participation of Eurasian JSC (one of the first Russian companies in the WSS sector, using the PPP model in the implementation of investment programs).

These include the comprehensive investment project, which is of national importance and is aimed at the development of water supply and sanitation systems of the Rostov agglomeration-the project "A comprehensive program for the construction and reconstruction of water supply and sanitation facilities in the city of Rostov-on-Don and the South-West of the Rostov Region". 
The study showed that the BOOT concession model was the best model of public-private partnership for this project.

The benefits of a PPP for a private partner should be attributed as the possibility of transferring a certain amount of risks to the public side (state), financing a long-term project with a constant return under guarantees/obligations of a public partner, increasing revenues (profits/revenues) from a PPP project by providing paid services and/or the use of unique solutions to reduce costs by attracting a public partner, and the reliability and protection of investment (in the future, the corporation (private partner) obtain the state-owned assets and orders for the objects of the agreement); guaranteed profitability (the private partner receives government guarantees for the return of investments on the project); relative autonomy (autonomy) in making operational decisions.

Advantages of a PPP for a public partner are the possibility of attracting a private investor to finance in order to create an object that will allow projects to be implemented, in the absence of budget funds to finance them; the ability to connect within the project different stages of the life cycle at the same time (design, construction, and operation), which will improve the quality of the object being created and will reduce the risks of overstating the cost of construction and operation of the object; the possibility of acquiring not an object, but subsequently services for which payments will be made, tied to the volume, and quality of their provision, which will contribute to the development of competition in the production of socially important services; reducing the cost of creating and maintaining a social or socially significant infrastructure in the framework of interaction with a private partner; reducing budgetary and other risks by sharing responsibility with a private partner; access to alternative sources of investment, which will allow us to implement socially important projects that were previously impossible.

Taking into account the different orientation of the interests of the PPP participants, in practice, achieving the complete combination of the interests of all participants in the partnership (the state, business, and society) is very difficult, but it can be achieved with the application of the proposed multi-criteria model for the coordination of interests. In this case, the intention is to achieve a synergistic effect in the framework of PPP projects. In the framework of integration, we can talk about a model of partial coincidence of the goals of the stakeholders and the achievement of a given synergistic effect based on the balance of interests of the participants. Finding all the possibilities for the coordination of interests between the participants of the partnership will expand the boundaries of the synergistic effect achieved.

Regarding the development of a cooperation mechanism in transboundary territories, the peculiarities of the territorial conjugation of neighboring regions in order to develop a common (cross-border) territory may find their development in border projects such as increasing the foreign economic potential of interregional cooperation in border regions of North-West Russia (in cooperation with Finland and Norway); cooperation of the Scandinavian and Baltic countries in solving global environmental problems; and development of the transport network, deepening of scientific and cultural cooperation, and environmental protection in the Eastern Donbass Euroregion and others.

\section{Conclusions}

It should be noted that PPP design at all stages is a multi-vector process in which the state, design and construction companies, creditors and equipment suppliers, investors (institutional, private, and international financial agencies), and users participate and interact. Due to the involvement of a large number of stakeholders in the preparation and implementation of the PPP project, and also due to the complexity of providing state guarantees, primarily financial (insurance and other sources of redundancy of risk coverage), the diversification of risks of implementing similar projects requires a systematic approach of meso- and microfactors, including the risk level of all partners of the PPP project, and long negotiation processes. An important principle of risk distribution is the principle of closing PPP risk by a participant who has the corresponding potential. 
Overcoming these risks is inextricably linked to improving the effectiveness of the mechanism of public-private partnership, primarily by developing a unified federal concept and specific programs for the development of PPP, which clear rules for sharing responsibilities and risks of partners, as well as their interaction will be defined. In addition, one of the most important priorities of the development strategy of this institution is the transformation of state policy is reorientation to the resource support of the innovative investment strategy and the expanded reproduction of quality human capital.

At the regional level, it is necessary to create administrative and coordinating structures (with the allocation in them of project development functional areas-social, innovative, transport, etc.) that could accelerate the development of the public-private partnership institution and thus contribute to regional economic growth quality improvement.

Author Contributions: Conceptualization, E.L., T.A. and G.O.; methodology, E.L., T.A. and G.O.; software, O.G.; validation, O.G.; formal analysis, G.O.; investigation, E.L. and A.M.; resources, O.G.; data curation, A.M.; Writing-Original Draft preparation, E.L., T.A. and A.M.; Writing-Review and Editing, E.L., T.A. and A.M.; visualization, E.L. and A.M.; supervision, E.L.; project administration A.M.

Funding: This work was supported by the Russian Foundation for Basic Research: project No. 18-010-00594.

Conflicts of Interest: The authors declare no conflict of interest.

\section{References}

1. Rosinfra. Simple and Honest about Infrastructure Investments and Public-Private Partnership in Russia: An Analytical Review; National Center for Public-Private Partnership: Moscow, Russia, 2019.

2. Delmon, J. Private Sector Investment in Infrastructure: Project Finance, PPP Projects and Risk; World Bank and Kluwer Law International: Washington, DC, USA, 2014; pp. 5-9.

3. Berezin, A.; Sergi, B.S.; Gorodnova, N. Efficiency Assessment of Public-private Partnership (PPP) Projects: The Case of Russia. Sustainability 2018, 10, 3713. [CrossRef]

4. Barro, R.J.; Sala-i-Martin, X. Economic Growth; MIT Press: Cambridge, MA, USA, 2004.

5. Hammond, J.S.; Ralph, L.; Keeney, H.R. Smart Choices: A Practical Guide to Making Better Life Decisions. New York: Crown Business. Heath, Chip and Dan Heath Decisive: How to Make Better Choices in Life and Work; Crown Business: New York, NY, USA, 2002.

6. Raiffa, H. Decision Analysis: Introductory Lectures on Choices Under Uncertainty; McGraw Hill: New York, NY, USA, 1997; ISBN 978-0-07-052579-5.

7. Park, B.U.; Simar, L.; Zelenyuk, V. Nonparametric estimation of dynamic discrete choice models for time series data. Comput. Stat. Data Anal. 2017, 108, 97-120. [CrossRef]

8. Anopchenko, T.; Lazareva, E.; Lozovitskaya, D.; Murzin, A. Analiz klyuchevyh parametrov ustojchivogo razvitiya regiona v usloviyah cifrovizacii ekonomiki. Sci. Educ. Househ. Econ. Entrep. Law Gov. 2019, 1, 7-12. (In Russian)

9. Lazareva, E.; Anopchenko, T.; Lozovitskaya, D. Identification of the city welfare economics strategic management innovative model in the global challenges conditions. In Proceedings of the 3rd International Multidisciplinary Scientific Conference on Social Sciences and Arts SGEM 2016, Albena, Bulgaria, 24-31 August 2016; Volume 4, pp. 3-10. [CrossRef]

10. Samsura, A.; Van der Krabben, E.; Van Deemen, A. A game theory approach to the analysis of land and property development processes. Land Use Policy 2010, 27, 564-578. [CrossRef]

11. Triantaphyllou, E. Multi-Criteria Decision Making Methods: A Comparative Study; Springer-Verlag US: Boston, MA, USA, 2000. [CrossRef]

12. Steele, K.; Stefánsson, H. Decision Theory. The Stanford Encyclopedia of Philosophy, Winter 2015 ed.; Edward, N., Zalta, E.N., Eds.; Metaphysics Research Lab, Center for the Study of Language and Information Stanford University: Palo Alto, CA, USA, 2015.

13. Gorbaneva, O.I.; Ougolnitsky, G.A. System Compatibility: Price of Anarchy and Control Mechanisms in the Models of Concordance of Private and Public Interests. Adv. Syst. Sci. Appl. 2015, 15, 45-59.

14. Ougolnitsky, G.; Anopchenko, T.; Gorbaneva, O.; Lazareva, E.; Murzin, A. Systems Methodology and Model Tools for Territorial Sustainable Development Management. Adv. Syst. Sci. Appl. 2018, 18, 136-150. 
15. Saaty, T.L.; Kearns, K.P. Analytical Planning; The Organization of Systems. Oxford, UK, NewYork, NY, USA, Toronto, ON, Sydney, NS. Pergamon Press: Frankfurt, Germany, 1985.

16. Tzeng, G.H.; Huang, J.J. Multiple Attribute Decision Making: Methods and Applications; GrChapman and Hall/CRC: Boca Raton, FL, USA, 2011.

17. Lazareva, E. Metody Modelirovaniya Innovatsionno-Oriyentirovannykh Ekonomicheskikh Strategiy Ekologoustoychivogo Razvitiya; Southern Federal University: Rostov-on-Don, Russia, 2011. (In Russian)

18. Lazareva, E. Modeli Ekologicheskoy Napravlennosti Investitsiy Chelovecheskogo Kapitala Gosudarstvenno-Chastnykh Strategiy $v$ Innovatsionnoy Ekonomike; Southern Federal University: Rostov-on-Don, Russia, 2012. (In Russian)

19. Kabashkin, V.; Levchenko, A.; Sidorov, V. Razvitiye Gosudarstvenno-Chastnogo Partnerstva v Regionakh Rossiyskoy Federatsii; Polytera: Belgorod, Russia, 2008. (In Russian)

20. Kazakov, V.V. Gosudarstvenno-chastnoe partnerstvo: mirovoy opit i otechestvennaya practica. Tomsk State Univ. J. 2014, 386, 165-171. (In Russian)

21. Yescombe, E.R. Public-Private: Partnerships Principles of Policy and Finance; Butterworth-Heinemann: Oxford, UK, 2007.

22. Regioni, R. Osnovnie Harakteristiki Sub'ektov Rossiyskoi Federacii [Regions of Russia. The Main Characteristics of the Constituent Entities of the Russian Federation]; Rosstat: Moscow, Russia, 2018. (In Russian)

23. Golden, B.L. The Analytic Hierarchy Process: Applications and Studies; Golden, B., Wasil, E.P., Eds.; Springer-Verlag: New York, NY, USA, 1989.

24. Lazareva, E.; Anopchenko, T.; Murzin, A. Forecasting development risks of regional economy. Competitive, Sustainable and Secure Development of the Regional Economy: Response to Global Challenges (CSSDRE 2018). In Proceedings of the International Scientific Conference; Advances in Economics, Business and Management Research (AEBMR), Volgograd, Russia, 18-20 April 2018.

25. Lazareva, E. Features of national welfare innovative potential parametric indication information-analytical tools system in the globalization trends' context. In Proceedings of the 9th International Conference on Information and Communication Technologies in Education, Research and Industrial Applications: Integration, Harmonization and Knowledge Transfer (ICTERI 2013), Kherson, Ukraine, 19-22 June 2013.

26. Bessant, J. (Ed.) Innovation in the twenty-first century. In Responsible Innovation: Managing the Responsible Emergence of Science and Innovation in Society; John Wiley \& Sons Ltd-Management Book Publishing: New York, NY, USA, 2013; Volume 44, pp. 1-25.

27. Anopchenko, T.Y.; Gorbaneva, O.I.; Lazareva, E.I.; Murzin, A.D.; Ougolnitsky, G.A. Dynamic model of coordination of general and private interests of the Russian Southern Federal district regions development. Adv. Syst. Sci. Appl. 2019. Accepted.

28. Hartwick, J.M. Intergenerational Equity and the Investing of Rents from Exhaustible Resources. Am. Econ. Rev. 1977, 67, 972-974.

29. Solow, R.M. Intergenerational Equity and Exhaustible Resources; Review of Economic Studies: London, UK, 1974; pp. 29-46.

(C) 2019 by the authors. Licensee MDPI, Basel, Switzerland. This article is an open access article distributed under the terms and conditions of the Creative Commons Attribution (CC BY) license (http://creativecommons.org/licenses/by/4.0/). 